\title{
Compound odontome: a tooth eruption disturbance
}

\author{
Ravi Prakah Sasankoti Mohan, ${ }^{1}$ Khushboo Rastogi, ${ }^{1}$ Sankalp Verma, ${ }^{2}$ \\ Rajarshi Bhushan ${ }^{1}$
}

${ }^{1}$ Kothiwal Dental College \& Research Centre, Moradabad, Uttar Pradesh, India ${ }^{2}$ Department of Oral Medicine and Radiology, Kothiwal Dental College \& Research Centre, Moradabad, Uttar Pradesh, India

\section{Correspondence to} Dr Khushboo Rastogi, diya2001_rastogi@yahoo.co.in

\section{DESCRIPTION}

Odontoma is perhaps more accurately defined as a hamartoma than a true neoplasm. ${ }^{1}$ The term odontoma was first coined by Broca in 1866, who defined it as a tumour formed by overgrowth of complete dental tissue. ${ }^{2}$ Odontoma has also been defined as 'tumour' that has developed and differentiated enough to produce enamel and dentin. ${ }^{3}$ Odontomas are usually composed of different dental tissues, including enamel, dentine, cementum and in some cases, pulp tissue. ${ }^{4}$

Although usually located pericoronally to an impacted tooth, odontoma may also arise from odontogenic progenitor cells within the periodontal ligaments and become located between the tooth root and are not associated with disturbance in eruption. ${ }^{5}$ Odontomas exhibit complete epithelial and mesenchymal differentiation to the point that enamel and dentin are formed. Gabell, James and Payne grouped odontoma according to their developmental origin: epithelial, composite (epithelial and mesodermal) and connective tissue. ${ }^{6}$ Clinically, odontomas are either complex or compound. Odontoma has a limited growth potential, but it should be removed because it contains various tooth formulations that can predispose to cystic change, thereby causing interference with eruption of permanent teeth and considerable destruction of bone. Therefore, we present a case of compound odontome with clinical presentation and radiographic analysis.

An 18-year-old male patient came to the department of orthodontics and dentofacial orthopaedics with non-eruption of lower right canine (figure 1). The patient was healthy and asymptomatic. His

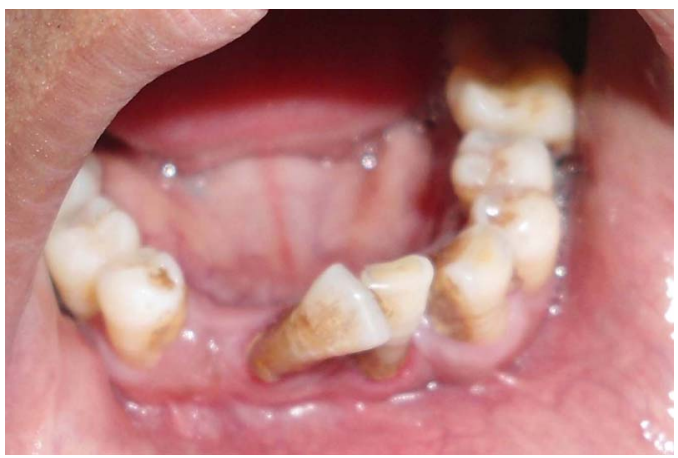

Figure 1 Intraoral view. dental and medical history was not significant. Intraoral examination revealed that \#42 and \#43 had not erupted in the oral cavity and right central incisor was overlapping the left central incisor. There was no sign of inflammation, pain or infection and the surrounding mucosa was normal. An intraoral periapical radiograph revealed the presence of \#43 deeply embedded in the alveolar bone. The root of the unerupted \#43 was overlapped by multiple well-defined radiopacities in the shape of miniature teeth as seen in figure 2 and almost covering the lower half of the unerupted \#43. The lesion was clinically asymptomatic. Based on the clinical and radiographic evaluation, a diagnosis of odontoma was made, although other pathological entities such as ameloblastic fibro-odontoma, osteoblastoma, ossifying fibroma or even osteoma may closely mimic an odontoma.

The mass was incised surgically under local anaesthesia, and histopathological examination of the incised mass confirmed the diagnosis of compound odontome.

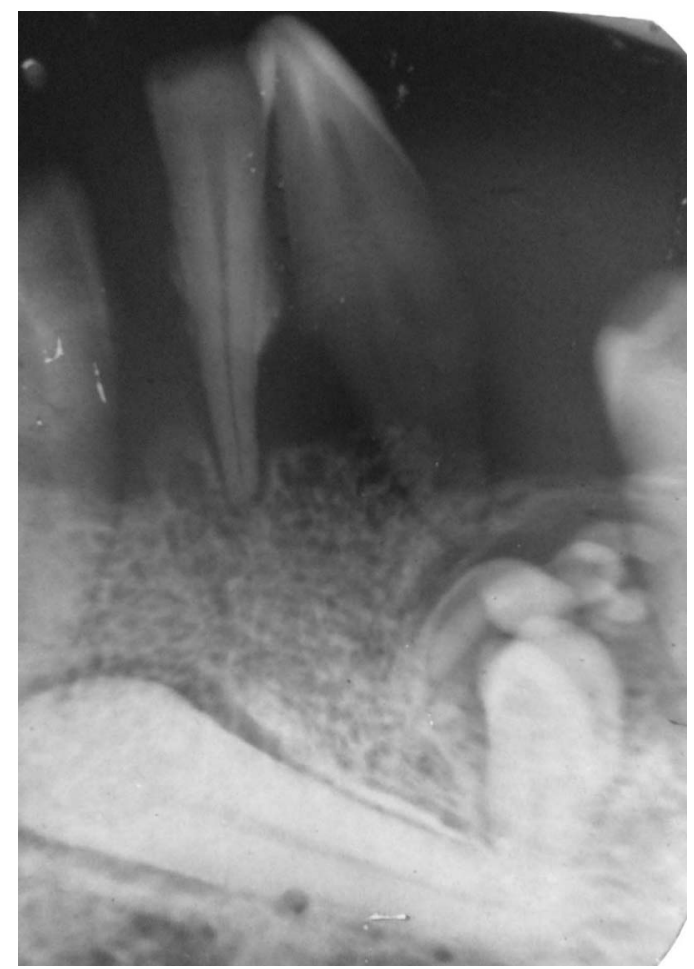

Figure 2 Radiographic view.

To cite: Mohan RPS, 


\section{Learning points}

- Understanding tooth development and eruption will guide a clinician to diagnose and differentiate normal from an abnormal.

- Constant evaluation about the dynamics of dentition is essential for the diagnosis and treatment of irregularities during this process.

- The presence of odontoma can delay the exfoliation of a deciduous tooth and the eruption of the permanent successors, which should be carefully observed.

- An odontoma has a limited growth potential, but it should be removed because it contains various tooth formulations that can predispose to cystic change, interference with eruption of permanent teeth and cause considerable destruction of bone.
Competing interests None.

Patient consent Obtained.

Provenance and peer review Not commissioned; externally peer reviewed.

\section{REFERENCES}

1 Teruhisa U, Murakami J, Hisatomi M, et al. A case of unerupted lower primary second molar associated with compound odontoma. Open Dentistry J 2009;3:173-6.

2 Cildir SK, Sencift K, Olgac V, et al. Delayed eruption of a mandibular primary cuspid associated with compound odontoma. J Contemp Dent Prac 2005;6:152-9.

3 Bhaskar SN. Odontogenic tumours of the jaws. In: Synopsis of oral pathology. 7th edn. New Delhi: CBS Publishers \& Distributors, 1990:260-308.

4 Gurdal P, Seckin T. Odontoma. Quintessence International 2001;4:32.

5 Shafer WG, Hine MK, Levy BM. A textbook of oral pathology. 6th edn. Philadelphia: Saunders, 2009:287-90.

6 Neville BW, Damm DD, Allen C, et al. Oral and maxillofacial Pathology 2nd edn. Philadelphia: Saunders, 2004:631-2.

Copyright 2013 BMJ Publishing Group. All rights reserved. For permission to reuse any of this content visit

http://group.bmj.com/group/rights-licensing/permissions.

BMJ Case Report Fellows may re-use this article for personal use and teaching without any further permission.

Become a Fellow of BMJ Case Reports today and you can:

- Submit as many cases as you like

- Enjoy fast sympathetic peer review and rapid publication of accepted articles

- Access all the published articles

- Re-use any of the published material for personal use and teaching without further permission

For information on Institutional Fellowships contact consortiasales@bmjgroup.com

Visit casereports.bmj.com for more articles like this and to become a Fellow 